\title{
ANTI-JUDAÏSME IN 'N JOODSE TEKS? DIE GEVAL VAN OPENBARING ${ }^{1}$
}

\author{
Prof Jan Willem van Henten \\ Universiteit van Amsterdam \\ Universiteit Stellenbosch
}

\begin{abstract}
This article offers a critical discussion of Peter Tomson's approach to Anti-Judaism in the New Testament (see his 'If this be from Heaven...' from 2001). Tomson rightly defines AntiJudaism as hatred of Jews and characterizes key passages in John's Gospel as anti-Jewish, but he assesses similar passages in Revelation differently because, in his opinion, Revelation would be a Jewish text and a Jewish text cannot be anti-Jewish. All relevant passages in Revelation are surveyed and a re-reading of two key passages, Rev 2:9 and 3:9, is offered. Tomson's argument about Revelation is refuted - also with the help of modern analogies, which suggest that a Jewish text can be anti-Jewish. The article ends with a brief personal note that calls for a reading of Revelation in Christian communities that is not hurtful for Jews.
\end{abstract}

Key Words: Anti-Judaism, Revelation, Stereotyping, Synagogue of Satan

\section{Inleiding}

In 2001 verskyn Peter Tomson se monografie oor anti-Judaïsme in die Nuwe Testament "If this be from Heaven...": Jesus and the New Testament Authors in their Relationship to Judaism. ${ }^{2}$ Soos uit die titel van die boek afgelei kan word, is 'n kombinasie van Handelinge 5:38-39 en Markus 11:30 hier ter sprake: Eerstens aan bod, is Rabbi Gamaliël se pleidooi om die vrylating van Jesus se volgelinge in die lig daarvan dat menslike oordeel oor die nuwe gemeenskap slegs voorlopig kan wees. Tweedens, Jesus se vraag aan die Joodse leiers in die tempel aangaande die doop van Johannes, naamlik of dit van die hemel of van mense kom. Die titel impliseer origens die vraag of Jesus van Nasaret se verskyning en handeling, en die daaruitvoortvloeiende vestiging van die Christendom inderdaad God se bedoeling was. Peter Tomson brei in dié boek uitvoerig uit op die kwessie van antiJudaïsme in die Nuwe Testament. Terwyl verskeie Bybelwetenskaplikes die relevante gedeeltes in die boek Openbaring binne hierdie konteks, veral Openbaring 2:9 en 3:9, in verband bring met Johannes 9:22, 34; 12:42 en 16:2 en ander welbekende Johannese gedeeltes wat dikwels as anti-Joods geïnterpreteer word, tref Tomson skerp onderskeid tussen die gedeeltes in Openbaring en dié in Johannes. Ek wil begin deur Tomson se karakterisering van die gedeeltes in Openbaring te ondersoek as nie anti-Joods nie en in samehang daarmee sy kriteria vir die bepaling van die anti-Joodse karakter van 'n Nuwe

Hierdie dokument is 'n geredigeerde vertaling van 'n lesing wat op 11 Mei 2010 deur prof JW van Henten in die Fakulteit Teologie van die Universiteit Stellenbosch tydens 'n Nuwe-Testamentiese Seminaar gelewer is. Met dié vertaling is geprobeer om so getrou moontlik aan die vorm en styl van die oorspronklike voordrag te voldoen.

2 The Biblical Seminar 76, Sheffield: Sheffield Academic Press, 2001. 
Testamentiese gedeelte bestudeer. In die tweede deel van my aanbieding wil ek Openbaring 2:9 en 3:9 bespreek, waarin 'n groep, genaamd: "dié wat sê hulle is Jode en nie is nie" in verband gebring word met "die sinagoge van Satan". Ek neem aan dat in dié frase: "die wat sê hulle is Jode" vir Peter Tomson verwys na ware Jode (of Judeërs, soos hulle ook bekend staan). In teenstelling met Tomson neig ek om die beeld van die Jode in Openbaring 2:9 en 3:9 as negatief en stereotiperend te lees. In die laaste instansie wil ek my persoonlike mening uitspreek en bespreek ten opsigte van die vraag of dit steeds sinvol is om vermelde gedeeltes in Openbaring in die konteks van gemeenskaplike Christelike samekomste te lees.

\section{Tomson se argument}

Peter Tomson se "If this be From Heaven..." bied 'n ondersoek na alle Nuwe Testamentiese gedeeltes relevant in die bespreking van anti-Judaïsme. Soos reeds in my inleidende opmerkings genoem, is die titel van dié boek om 'n baie spesifieke rede gekies, aangesien die vraag gestel gaan word of God bedoel het dat Jesus, die Messias en stigter van 'n nuwe godsdiens, losstaande van Judaïsme, moes wees. Dit is egter opmerklik dat Tomson beswaarlik dié vraag probeer beantwoord. Waarop hy wél uitbrei, is 'n onderwerp wat reeds in die inleiding van sy boek ter sprake is, naamlik die paradoks ten opsigte van die benaminge in genoemde tekste. Hy argumenteer op grond daarvan dat die Nuwe Testament terselfdertyd 'n Joodse en 'n anti-Joodse boek is. Hy begelei sy lesers op gedetaileerde herlesings van elke Nuwe Testamentiese geskrif ten einde te probeer vasstel hoe die Joodse karakter en die haat vir Jode hand aan hand loop daarin. Daarom dring hy aan op 'n herassessering van die Joodse wortels betreffende Christelik tradisies aan die een kant, en 'n ernstige studie van die eintlike oorsprong van die Christen-haat vir Jode wat in die Shoa kulmineer. Tomson definieer deurgaans anti-Judaïsme as godsdiensgemotiveerde haat vir Jode. ${ }^{3}$ Hy nooi sy lesers om deel te neem aan 'n proses wat die herlees behels van Nuwe Testamentiese geskrifte, wat hy as histories van toepassing daarop beskou. ${ }^{4}$ In die herlees van dié geskrifte bespeur Tomson telkens spanning wat tot uiting kom in stellings wat die Jode raak. Hy kom tot die gevolgtrekking dat onderskei kan word tussen tekstuele strata met veranderende perspektiewe ten opsigte van die verhouding met (mede-)Jode, binne die Nuwe Testamentiese geskrifte afsonderlik en die Nuwe Testament as geheel. ${ }^{5}$

Vir die doel van my bespreking, is dit belangrik om daarvan kennis te neem dat Peter Tomson elke Nuwe Testamentiese geskrif kontekstualiseer ten opsigte van een van ses vroeë Christelike milieus waartussen hy op grond van die verskil in perspektief rakende die Jode onderskei. Die milieus en die Nuwe Testamentiese geskrifte daarmee verbind, is:

- Die historiese Jesus en die tradisie van sy uitsprake en handelinge (veral die oudste strata in Markus, Matteus en Lukas). Jesus en sy onmiddellike volgelinge het 'n interne Joodse beweging gevorm, wat geen kwade gevoelens jeens Jode gekoester het nie.

- Die 'Joodse kerke' (Jakobus, Judas, die Didaché, die Joods-Christelike strata van Matteus, Hebreërs en Openbaring).

- Die Pauliniese tradisies en nie-Joodse kerke (die Pauliniese korpus en LukasHandelinge), wat 'n positiewe houding teenoor die oudste gemeenskap in Jerusalem

\footnotetext{
${ }^{3}$ Tomson, "If This Be From Heaven...", 20.

${ }^{4}$ Tomson, "If This Be From Heaven... ", 16-19.

${ }^{5}$ Tomson, "If This Be From Heaven...", 19.
} 
gehad het, maar 'n pluralistiese groepsamestelling vertoon het rakende Joodse en nie-Joodse lede.

- Die Johannese milieu met sy tipiese demonisering van die opponent (Johannese briewe, kyk 1 Johannes 3:8, 15; vgl. Johannes 8:31; Die Evangelie van Johannes).

- Die milieu waarbinne die Evangelie van Markus en die finale weergawe van die Evangelie van Matteus ontstaan het. Tomson kom tot die gevolgtrekking dat albei dié evangelies redaksionele wysigings ondergaan het wat van 'n anti-Joodse sentiment getuig (Matteus in 'n sterker mate as Markus). Tog, sou dit oordrewe wees om van die "goed-gefundeerde haat vir Jode" in Markus te praat. Die finale redakteur van Matteus blyk 'n anti-Joodse persoon met 'n Joods-Christelike agtergrond te gewees het.

- Die milieu van die Gnostiese Evangelies (Evangelie van Thomas en die Evangelie van Filip).

Ek wil op Openbaring fokus en gaan eerstens probeer vasstel wat Tomson se beskouinge ten opsigte van die laaste boek van die Christelike Bybel is. Openbaring het volgens hom ontstaan in, wat hy, met 'n hoogs dubbelsinnige frase beskryf as die Joodse kerke, met ander woorde, plaaslike Jode-gemeenskappe wat ander tradisies met betrekking tot Jesus gedeel het as die lees van die Torah in die sinagoge. Hierdie milieu is egter nie gekenmerk deur 'n openheid jeens nie-Jode in dié mate wat Paulus voorgestaan het nie.

Dit is ook betekenisvol dat Peter Tomson Openbaring duidelik van ander Johannese geskrifte onderskei, omdat daarin nie 'n spesifieke Joodse groep aangespreek word nie, maar Jode in die algemeen. "...the Gospel in its entirety addresses itself against the Jews as such. The cited passage [John 8:31, 44] explicitly speaks out against Jewish Christians, who in one breath are designated with clear dissociations, as 'the Jews' (Jn 8.48). ...The Gospel of John in its final form reflects a milieu that had come entirely free of Judaism, so that the intra-Jewish diabolization in this final phase is transferred to 'the Jews' in general. This must have been done by a redactor who placed himself outside of the context of Judaism". ${ }^{6}$ Tomson beskou Johannes 8 as die klassieke ontstaanspunt van die Christelike haat teenoor Jode. ${ }^{7}$ Hierdie haat in Johannes was, volgens sy mening, die gevolg van 'n proses waardeur die opponent as diabolies verklaar is: Hierdie diabolisering is van toepassing gemaak op alle Jode wat na die finale skeiding tussen die Jesus-beweging en die Judaïsme nie as navolgers van Jesus beskou is nie. Openbaring is egter vir Tomson iets heeltemal anders. ${ }^{8}$

\section{Anti-Judaïsme in Openbaring, of: Kan 'n Joodse teks anti-Joods wees?}

Ek het reeds daarop gewys dat Peter Tomson die Boek Openbaring as 'n Joodse werk beskou, met sy oorsprong in Joodse kerke, en dat dit volgens sy mening, nie haat teenoor Jode weerspieël nie. Sy argument ter motivering van Openbaring as 'n Joodse geskrif word gesteun deur die onlangse proefskrif deur John Marshall. Anders as Tomson sien Marshall

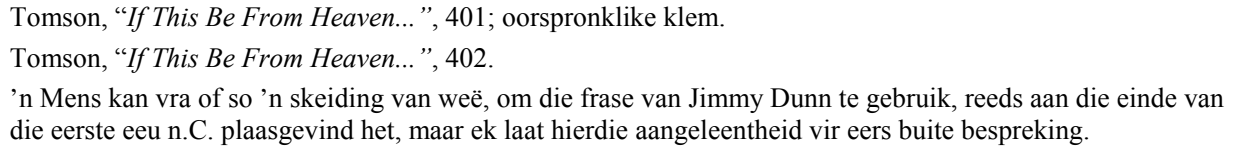


af van die klassifikasie 'Christen' rakende Openbaring. ${ }^{9}$ Tomson beskou egter Openbaring as 'n Joods-Christelike werk op grond van drie waarnemings:

1) Openbaring inkorporeer alle tipes Joodse tradisies;

2) Dit bied 'n positiewe beeld van Jerusalem;

3) Die demonisering van Jode in 2:9 en 3:9 moet teen die agtergrond van 'n interne Joodse perspektief geïnterpreteer word. Dit impliseer dat dit nie eenvoudig getuig van haat vir Jode nie. Ek bespreek kortliks dié drie waarnemings.

Eerstens is die Joodse kenmerke van Openbaring inderdaad betekenisvol vir hierdie bespreking. Gerard Mussies se diepgaande morfologie-studie van die Grieks wat in Openbaring gebruik is, lei tot die gevolgtrekking dat die agtergrond van die boek onteenseglik Joods is; dat die outeur tweetalig of multi-talig was en oor 'n grondige kennis van Hebreeus en Aramees beskik het, of, anders kan die herhaaldelike voorkoms van Semitismes daarin dui op 'n oorspronklike Semitiese bron wat deur 'n Christen van Joodse oorsprong vertaal is. ${ }^{10}$ Geen ander Nuwe Testamentiese geskrif bevat soveel verwysings na gedeeltes wat behoort tot dít wat die Hebreeuse Bybel geword het nie. Die siening wat steeds deur sommige geleerdes voorgestaan word, naamlik dat Openbaring nie enige aanhalings in Joodse skrif bied nie, kan maklik weerlê word. Let op die drie aanhalings van Ps 2:9 in Openbaring $2: 27 ; 12: 5$ en 19:15. Openbaring bevat merkwaardig baie verwysings na gedeeltes uit die Joodse Bybel en toon ook sterk ooreenkoms met Joodse eksegetiese tradisies. Daar is byvoorbeeld sterk parallelle met gedeeltes van die Targumim oor die Profete. ${ }^{11}$

Tweedens is die Profeet Johannes ${ }^{12}$ se beskrywing van Jerusalem meer gekompliseerd as wat Peter Tomson toegee en ook nie deurgaans positief nie. Tomson beskou die wyse waarop Christelike outeurs onderskei tussen die hemelse Jerusalem aan die een kant en die aardse Jerusalem aan die ander kant as ' $n$ belangrike aanduiding ter bepaling van die antiJoodse karakter van 'n geskrif, al dan nie. Vir hom is die Christelike redaksie van die Joodse apokalips van 4 Ezra'n duidelike voorbeeld hiervan. Daarin word die hemelse Jerusalem gestel teenoor die aardse Jerusalem en word die vernietiging van Jerusalem as ' $\mathrm{n}$ bewys van die onterwing van die Jode deur God geïnterpreteer (4 Ezra 1-2). ${ }^{13}$ Die verskillende verwysings na Jerusalem in Openbaring weerspreek mekaar op die oog af. Die afsluiting van die visioene met die visioen van die groot hemelse Jerusalem in hoofstuk 21 is natuurlik positief. Tog word die aardse Jerusalem in Open 11:8 'die groot stad' genoem, soos Rome, wat duidelik in die boek 'n baie negatiewe konnotasie het. Voorts word

9 JW Marshall, Parables of War: Reading John's Jewish Apocalypse, Studies in Christianity and

Judaism/Études sur le christianisme et le judaïsme. Waterloo, Ont.: Wilfrid Laurier University Press, 2001.

10 G Mussies, The Morphology of Koine Greek as Used in the Apocalypse of St John: a Study in Bilingualism, Leiden: Brill, 1971:311-2.

11 Daar is verskeie gevallestudies [verskeie gevalle van studies?] ten opsigte van die gebruik van spesifieke boeke uit die Joodse Bybel in Openbaring; sien o.a., GK Beale, The Use of Daniel in Jewish Apocalyptic Literature and in the Revelation of St. John, Lanham-New York-London: University Press of America, 1984; J-P Ruiz, Ezekiel in the Apocalypse. The Transformation of Prophetic Language in Revelation 16,17-19,10, European University Studies, Series 23; Theology 376, Frankfurt-Bern-New York-Paris: Lang, 1989; J Fekkes, Isaiah and Prophetic Traditions in the Book of Revelation, JSNT Supplement Series 93, Sheffield: Sheffield Academic Press, 1994. Sintese kan gevind word in S Moyise, The Old Testament in the Book of Revelation, JSNTSup, 115, Sheffield: Sheffield Academic Press, 1995, en GK Beale, John's Use of the Old Testament in Revelation, JSNTSup, 166, Sheffield: Sheffield Academic Press, 1998.

12 DE Aune, "The Prophetic Circle of John of Patmos and the Exegesis of Revelation 22.16", JSNT 37 (1989) 103-116.

13 Tomson, 'If This Be From Heaven...', 368. 
Jerusalem in geestelike terme "Sodom en Egipte, waar ook onse Here gekruisig is" genoem. Dit wil dus voorkom asof Jerusalem in Openbaring positiewe en negatiewe konnotasies het. Tomson sluit af met die gedagte dat die aardse Jerusalem sonder die tempel in haar toekomstige glorie sal saamloop met die hemelse Jerusalem. Hy verreken egter nie die diskrepansies aangaande Jerusalem met inagneming van die verskillende strata van die Openbaringteks, soos hy in ander gevalle doen nie. ${ }^{14} \mathrm{En}$, die belangrikste is dat hy geen bewyse ten opsigte van anti-Judaïsme in hierdie gedeeltes vind nie. Dit wil voorkom asof Tomson Openbaring 11 te oppervlakkig bestudeer het. Die visioen in dié hoofstuk skets die lotgevalle van twee getuies wat ooreenkomste met Moses en Elia toon, maar wat waarskynlik eerder gebaseer is op twee profete wat Jesus, die Messias, volg en wat dieselfde verskriklike ervaring as die twee getuies sal meemaak. Na hulle dood in hoofstuk 13, wat deur die eerste ongedierte veroorsaak is, sal hulle liggame vir drie en 'n halwe dae in die strate van 'die groot stad' lê (11:8). 'Drie en 'n halwe dag' is 'n spesifieke vorm van tydsaanduiding wat herhaaldelik in die visioene opduik. Dit mag verwys na 'n apokaliptiese periode, wat 'n aanvang neem met Jesus se dood en uitloop op die duisendjarige koninkryk. Die assosiasie van Jerusalem met Rome na aanleiding van die sleutelterm 'die groot stad' (11:8; vgl. 16:19; 17:18; 18:10, 16, 19, 21), die verwysing na Jesus se kruisiging, en die assosiasie van Jerusalem met Sodom en Egipte versterk die gevolgtrekking dat Jerusalem negatief uitgebeeld word. In die lig van verskeie gedeeltes in die Hebreeuse Bybel blyk Jerusalem se verband met Sodom 'n sterk diskwalifikasie vir 'n enkelduidige positiewe evaluering van Jerusalem te wees (Deut. 17:16; Jes. 1:9-10; Jer. 23:14; Eseg. 16:46-58). ${ }^{15}$ Dit laat my wonder of die verwysings na die hemelse tempel in Openbaring 7:15; 11:19 en 15:5, asook die visioen van die hemelse Jerusalem in 21 gekombineer met die sterk negatiewe uitbeelding van Jerusalem in hoofstuk 11 nie sterker vergelykbaar is met die anti-Joodse verwerking van 4 Ezra nie.

Derdens, die belangrikste aanduiding van anti-Judaïsme in Openbaring is die dubbele assosiasie van "hulle wat sê hulle is Jode" met die "sinagoge van Satan" in 2:9 en 3:9. Peter Tomson interpreteer nie dié gedeeltes in die boodskappe aan die gemeenskappe van Smirna en Philadelphia as anti-Joods nie. Hy stel voor dat dié gedeelte geïnterpreteer word as synde gerig op Jode in die etniese en kultureel-religieuse sin van die woord en nie op Christene as sodanig $^{16}$ simpatiseerders met Judaïsme uit die geledere van heidene, Judeërs of 'half-Jode' nie $^{17}$ - soos deur sommige geleerdes gemeen nie. Tomson veronderstel dat die Jode hier ter sprake meer geneig sou wees tot 'n kompromie met die Romeinse outoriteite as die groep rondom Johannes, die outeur van Openbaring. ${ }^{18}$ Hy wys daarop dat die benaming: Jode (Ioudaioi) as sodanig, 'n positiewe konnotasie in hierdie gedeeltes het, soos ook die geval in Paulus se briewe. Die outeur beweer dus dat die Jode van Smirna en Filadelfia die goeie

14 Tomson, 'If This Be From Heaven... ', 362-80.

15 MJ Mulder, Sodom en Gomorra: een verhaal van dode steden, Exegetische studies 4, Kampen: Kok, 1988; JA Loader, A Tale of Two Cities. Sodom and Gomorrah in the Old Testament. Early Jewish and Early Christian Traditions, CBET, 1, Kampen: Kok, 1990; WW Fields, Sodom and Gomorrah. History and Motif in Biblical Narrative, JSOTSup, 231, Sheffield: Sheffield Academic Press, 1997.

16 H Kraft, Die Offenbarung des Johannes, Handbuch zum Neuen Testament 16a, Tübingen: Mohr Siebeck, 1974, 60-1.

17 Die laaste voorstel is van LH Feldman, Jew and Gentile in the Ancient World: Attitudes and Interactions from Alexander to Justinian, Princeton: Princeton University Press, 1993, 357 with n. 47.

18 Tomson, 'If This Be From Heaven... ', 375 
naam van die Jode gediskrediteer het. So 'n appèl teen die benaming Jood kan, na Tomson se mening, gevind word in Pauliniese gedeeltes, asook in Rabbynse literatuur. ${ }^{19}$

Dit kom dus daarop neer dat Peter Tomson nie enige motivering vind om Openbaring as 'n anti-Joodse geskrif te beskou nie. 'n Belangrike punt in sy argument teen die anti-Joodse karakter van dié geskrif, is gebaseer op die feit dat die negatiewe sentimente oor Jode deel van interne Joodse konflik was. ${ }^{20}$ Die beswaddering en demonisering van Jode in Openbaring is dus ' $n$ interne Joodse aangeleentheid. Die demonisering van Joodse opponente kan as anti-Joods gekarakteriseer word wanneer dit spruit uit konflik tussen Joodse en nieJoodse Christene, soos die geval in die Evangelie van Johannes. ${ }^{21}$ Tomson se argument blyk egter ' $n$ dwaling te wees. Dit maak nie sin dat slegs nie-Jode as anti-Joods beskou kan word nie. Twee moderne analogieë kan ingespan word om die argument van Tomson te weerlê. Sekere Amerikaners is tussen 1938 en $1954^{22}$ deur die "Committee on Un-American Activities of the US House of Representatives" as anti-Amerikaans geklassifiseer. Die Joseph R (Joe) McCarthy-era word gekenmerk deur die venynige oor-en-weer haat van regeringsmense en hulle (veronderstelde) opponente. Lesers van die Israeli-koerante sal niks daarvan dink om om stellings deur lede van die moderne Staat behorende tot ander Joodse groeperings as dié waartoe hulle behoort, as anti-Judaïsties af te maak nie - of selfs hulle opponente met uiters negatiewe frases soos fasciste, neo-Nazi's, of neo-Hitlers te stereotipeer. ${ }^{23}$ Hierdie reaksie is in die eerste plek te wyte aan komplekse ideologiese konflikte en hou ook verband met sosiale konflikte en groepsprosesse. Deur terme soos Judaïsme of anti-Judaïsme word spesifieke groepe geïdentifiseer. Deur Judaïsme op 'n ekstreme of baie spesifieke wyse te definieer, word alle mense wat nie aan die eienskappe van hierdie definisie voldoen nie - Jood of nie-Jood - buitestaanders. As dit hand aan hand gaan met die handelinge van stereotipering en haat, kan die Joodse deel van hierdie buitestanders die slagoffers van Joodse anti-Judaïsme word.

In die volgende gedeelte wil ek Peter Tomson se argument omdraai en my siening verdedig deur nog 'n analogie te bespreek, waarna Tomson self verwys, naamlik die Dooie See Rolle. Hy kom tot die gevolgtrekking dat Openbaring 2:9 en 3:9 nie 'n anti-Joodse karakter het nie omdat: "It is important here [re: Openbaring 2:9; 3:9], just as in the Qumran scrolls and in the pseudepigraphical texts, the reference is to Jews being judged by fellow-Jews...." ${ }^{4}$ Dit is algemeen bekend dat die Qumran-gemeenskap of -gemeenskappe 'n skerp onderskeiding tussen binnestaander- en buitestaander-groepe getref het. Aan die binnestaander-groep het die heidene sowel as al die Jode wat nie lede van die in-groep was nie, behoort. Die buitestaander-groepe is gedemoniseer deur ekstreme negatiewe kwalifikasies bekend met die demonisering van Jode soos gevind word in Johannes 8:44 en Openbaring 2:9 en 3:9. 'n Paar verwysings is voldoende, soos: die mense van boosheid (1 QS 5:1-2, 10-20), die kinders van duisternis (1 QM 1:1 en elders), die gemeenskap van

Tomson, 'If This Be From Heaven... ', 376-7.

20 Baie ander geleerdes aanvaar ook dat slegs nie-Jode hulleself skuldig maak aan anti-Judaïsme, kyk bv. L Schottroff \& MT Wacker (red.), Von der Wurzel getragen. Christlich-feministische Exegese in Auseinandersetzung mit Antijudaismus, Leiden: Brill, 1996, 156.

21 Tomson, 'If This Be From Heaven... ', 394.

22 Ek bedank John Marshall wat dit aan my uitgewys het.

23 Kyk onder meer A Oz, In the Land of Israel, met'n nuwe epiloog, San Diego: Powell's Books, 1993. Kyk ten opsigte van stereotipering ook J Punt, "Post-Apartheid Racism in South Africa: The Bible, Social identity and Stereotyping", Religion and Theology 16 (2009), 246-72.

24 Tomson, 'If This Be From Heaven... ', 394. 
Belial $^{25}$ (1 QH 2:22 en elders), of die leer van Belial (1 QM 1:1; vgl. 1QS 2:4-5 en 1QM 4:1-2), teenoor wie die gemeenskap van God oorlog moet voer (1 QM 4:9-10). Die Qumran-gemeenskap het hulself nie beperk tot die swartsmeer van buitestaander-groepe nie, maar ook deelgeneem aan die rituele eliminering van hulle buitestaander-opponente, soos 'n teks met vloek-formules aangaande Belial en sy kinders uitwys (4 Q286 10 2). ${ }^{26}$ Ongeag die klassifikasie van die Oorlog Rol as 'n millitêre handboek of nie - hierdie dokument (1 QM; vgl. 4 Q492 en 4 Q494-6) ontwikkel in elk geval in een van sy stratum 'n scenario van 'n eskatologiese oorlog waarin die kinders van die lig uiteindelik triomfeer oor dié van die duisternis (1 QM 1:13-15; 1 QM 14-19). Die kinders van die duisternis kan geïdentifiseer word as Belial en sy medewerkers en die scenario loop ten einde met hulle algehele vernietiging (1QM 18:2-3). ${ }^{27}$ Die Qumran-gemeenskap is gevorm deur Jode en die meeste van hulle opponente moes ook Jode gewees het. Ek beskou die Qumrangemeenskap se diskwalifikasie van diegene wat na hulle mening die buitestaander-Joodse groep was as 'n uitdrukking van anti-Judaïsme, omdat dit na my mening aan Tomson se kriteria van die manifestasie van haat teenoor Jode voldoen.

\section{'n Herlees van Openbaring 2:9 en 3:9}

My bespreking van Tomson se benadering tot anti-Judaïsme het gelei tot 'n kontrasterende gevolgtrekking, naamlik dat Joodse tekste, ten minste in beginsel, anti-Joods kan wees. Die analogie tussen Openbaring en die Qumran-gedeeltes, wat in albei gevalle Joodse buitestaander-groepe met Satan of Belial, soos Satan dikwels in Qumran-gedeeltes genoem word, in verband bring, help ons ook om te onderskei tussen negatiewe stereotipering en scenario's wat stereotipering insluit, maar voorsien ook die vernietiging van die buitestaander-Joodse groep. Natuurlik is die derde stap van anti-Judaïsme die vernietigende gevolg van sulke scenario's - daadwerklike dade wat spruit uit die haat teenoor Jode. In die lig van hierdie opmerkings oor anti-Judaïsme wil ek dan Openb. 2:9 en 3:9 nou interpreteer.

Die sewe briewe aan Jesus se volgelinge in die sewe gemeentes in die Romeinse KleinAsië is in der waarheid verordeninge van Jesus $(2: 1,8,12,18,3: 1,7,14)$. Hierdie sewe boodskappe bespreek in simboliese taal aspekte van die onderskeie gemeenskappe se situasies teen die agtergrond van hulle kulturele en religieuse konteks binne die stedelike milieu van die Romeinse provinsie van Asië. Joodse gemeenskappe was beslis deel van dié wêreld en het aan die einde van die eerste en die begin van die tweede eeu Jesus se navolgers getalsgewys ver oortref. ${ }^{28}$ Die situasie van die gemeente in Smirna word soos volg in Openbaring 2:9 aangedui: "Ek ken jou werke en verdrukking en armoede - maar jy is ryk - en die lastering van die wat sê dat hulle Jode is, en dit nie is nie, maar 'n sinagoge van die Satan". ${ }^{29}$ Die aanvegting in vers 9 word nie gespesifiseer nie, maar hang moontlik

25 Belial is 'n alternatiewe naam vir Satan, A Sperling, 'Belial,' in: Dictionary of Deities and Demons in the Bible (red. K van der Toorn, B Becking en PW van der Horst; 2de uitgawe; Leiden-New York-Köln: Brill, 1999), 169-171.

26 PJ Kobelski, Melchizedek and Melchiresa, CBQ Monograph Series 10; Washington: Catholic Biblical Association of America, 1981.

27 F Garcia Martinez, “Apocalyptiek in de Dode Zee rollen”, in: JW van Henten \& AO Mellink (red.), Visioenen aangaande het einde: Apocalyptische geschriften en bewegingen door de eeuwen heen, Zoetermeer: Boekencentrum, 1998, 94-102, bied 'n netjiese ondersoek.

28 P Trebilco, Jewish Communities in Asia Minor, SNTS MS, 69, Cambridge: Cambridge University Press, 1991.

29 Tensy anders gespesifiseer word die OAV-vertaling (1933/1953) vir die aanhaling van Bybelse gedeeltes gebruik. 
saam met die aanvegting van die Satan in vers 10: "Vrees vir niks wat jy sal ly nie. Kyk, die duiwel gaan sommige van julle in die gevangenis werp sodat julle op die proef gestel kan word; en julle sal tien dae lank verdrukking hê". Die skynbaar teenstrydige stelling oor rykdom en armoede betreffende Jesus se volgelinge in Smirna kan letterlik opgeneem word met betrekking tot die armoede (vgl. 13:16). Die mees waarskynlike interpretasie is dat dit vir mense wat nie van enige kompromie met die eksterne stedelike wêreld wou hoor nie, baie moeilik was om te oorleef. Die term, rykdom, kan metafories geïnterpreteer word. Dit kan verwys na die eskatologiese verlossing soos in Matt. 3:3 of Luk. 6:20.

Die interpretasie ten opsigte van diegene ter sprake in: "die wat sê dat hulle Jode is, en dit nie is nie" as synde inderdaad Jode, word onder andere voorgestel deur RH Charles, C Hemer, A Yarbro Collins, E Schüssler Fiorenza en DE Aune en word as die meerderheidsiening beskou. ${ }^{30}$ Hierdie siening is skerp gekritiseer deur John Marshall in sy proefskrif Parables of War: Reading the Apocalypse within Judaism and during the Judean War, waarvan ek vroeër melding gemaak het. Marshall dateer Openbaring as synde 69-70 n.C. en kom tot die gevolgtrekking dat die boek geskryf is met die doel om insig aan sy lesers te bied ten opsigte van die Joodse konflik met Rome, die oorlog se gevolge vir die Jode in die Diaspora en hulle van riglyne te voorsien ten opsigte van hul verhouding met Rome en die breër Grieks-Romeinse kultuur. Die onderskeiding in Openbaring tussen binne- en buitestaanders sou volgens Marshall dui op Jode aan die een kant en die Grieks-Romeinse buitewêreld aan die ander kant. ${ }^{31}$ Die konflik-aangeleentheid wat in Openbaring 2:9 en 3:9 aan die orde is, is volgens hom te wyte aan die kwessie rakende dieeet, al dan nie van 'afgode-vleis', wat blyk uit ander tekste in Openbaring 2-3. ${ }^{32}$ Daarom sou Openbaring 2:9; 3:9 kon beteken: "Nie-Jode sê dat hulle Jode is en Johannes antwoord, in effek, slegs in soverre hulle 'n sinagoge van die Satan is".33 Marshall se argument is gebou op waardevolle observasies en van sy kritiek teen bestaande beskouinge blyk geregverdig te wees. Om Openbaring as 'n Joods-apokaliptiese geskrif te lees, kan inderdaad sinvol wees indien aanvaar word dat Christendom sy beslag gekry het deur die geleidelike en variërende prosesse, wat moontlik kon duur tot selfs 'n geruime tyd na die dood van Jesus. ${ }^{34}$

Die voorstel dat by gebrek aan bewyse van konflik tussen Jode en Christene as aparte groepe in Openbaring ook in Openbaring 2:9 en 3:9 opsy geskuif kan word, deur Yarbro Collins, is ook 'n opsie. ${ }^{35}$ Marshall wys tereg daarop dat Openbaring se apokaliptiese scenario, in die oordeel-gedeeltes nie verwys na die straf van Jode nie. ${ }^{36}$ Tog oorweeg ek die siening dat in Openbaring 2:9 en 3:9 na die Jode verwys, steeds as die mees waarskynlike

30 Vir verwysings kyk Marshall, Parables, 19-23; 70-1; D Frankfurter, “Jews or Not? Reconstructing the 'Other' in Revelation 2:9 and 3:9”, HThR 94 (2001), 403-25; A Frilingos, Spectacles of Empire: Monsters, Martyrs, and the Book of Revelation, Philadelphia: University of Pennsylvania Press, 2004, 109.

31 Marshall, Parables, 263; 266; 288.

32 Marshall, Parables, 71; 181-2; 196.

33 Marshall, Parables, 19. Marshall blyk sy eie argument te ondermyn wanneer hy voorstel dat die opponentegroep in Op. 2:9; 3:9 saamgestel is uit ' $\mathrm{n}$ “.... mixture of Pagan Godfearers and comfortably hellenizing Jews who welcome the Godfearers without requiring a substantial (in John's eyes) separation from Greco-Roman culture in either themselves or their adherents..." Parables, 198.

34 Vgl. Van Henten, "Christenen binnen en buiten het Jodendom” in T Baarda, HJ de Jonge en MJJ Menken (red.), Jodendom en vroeg christendom: continuïteit en discontinuïteit, Kampen: Kok, 1991, 137-61.

35 A Yabro Collins, "Insiders and Outsiders in the Book of Revelation and its Social Context", in: J Neusner \& ES Frerichs (red.), To See Ourselves as Others See Us. Christians, Jews, and 'Others' in Late Antiquity, Chico, Calif.: Society of Biblical Literature, 1985, 187-218 (217); "Vilification and Self-Definition in the Book of Revelation”, HThR 79 (1986), 308-320 (313).

36 Marshall, Parables, 274. 
interpretasie daarvan. Eerstens, word kos nie eksplisiet genoem as die verdelende kwessie in die boodskap aan Smirna nie. Tweedens, verwys Openbaring 2:9 eerder na ' $n$ ander kwessie van konflik, naamlik dié van lastering "van die wat sê dat hulle Jode is" en "die sinagoge van Satan", in dieselfde sin en dit dui meer waarskynlik op Joodse opponente as die nie-Joodse opponente, aangesien die term, 'n sinagoge, duidelik 'n Joodse konteks veronderstel. Derdens, maak die verwysing na Jesaja 60:14 in Openbaring 3:9 nie regtig sin as dié wat sê dat hulle Jode is, as nie-Jode gesien moet word nie (kyk onder). Na my mening is Openbaring 3:9 juis 'n omkering van die oorspronklike betekenis van Jesaja 60 . Dit impliseer naamlik dat dié wat sê dat hulle Jode is, in werklikheid heidene is en nie Israel in die ware sin van die woord nie. Indien hulle inderdaad heidene was, sou dié polemiek se slaankrag nogal sterk daardeur ondergrawe word.

Die frase: sinagoge van Satan, wat dui op 'n sinagoge met 'n sataniese karakter, of 'n sinagoge wat aan Satan behoort, ${ }^{37}$ verwys heel moontlik na die samekoms van die Joodse gemeenskap en nie die gebou nie. Die lastering word nie gespesifiseer nie. Dit kan moontlik verwys na lastering van God (soos in Markus 2:7; Openbaring 13:6), deur byvoorbeeld te ontken dat Jesus die Messias was. Verskeie kommentatore veronderstel dat hier sprake is van Christene wat deur Jode gerapporteer word aan die Romeinse outoriteite ingevolge die sogenaamde cognitio-prosedure. ${ }^{38}$ Dié interpretasie word ondersteun deur die stelling in vers 10, wat impliseer dat die sogenaamde Jode, die Christene aan die outoriteite gerapporteer het. Die rapportering het wrede gevolge gehad. Die kwessie hier ter sprake, is dus 'n erger vergryp as anti-Judaïsme of antichristelike dade deur Jode.

Colin Hemer argumenteer dat Openbaring 2:9 by uitstek oor die vervolging van Christene deur Jode handel. Hy staaf sy argument deur te verwys na veronderstelde anti-Joodse gedeeltes in Martelaarskap van Polycarpus en Martelaarskap van Pionius:

Daar word vertel van Jode wat hulle daarin verheug het om die outoriteite by te staan met die teregstelling van die Christelike helde ("soos hulle gewoond was om te doen," Mart. Pol. 12.2, Mart. Pion. 4) ${ }^{39}$ 'n Tweede motivering vir Hemer se interpretasie is dat die vervolging van Christene, aldus sy opinie, plaasgevind het gedurende die tyd van Domitianus. ${ }^{40}$ Albei hierdie argumente moet afgewys word. Daar is egter nie grondige bewyse dat Domitianus verantwoordelik was vir die vervolging van Christene in KleinAsië nie. ${ }^{41}$ Die Martelaarskap van Polycarpus en die Martelaarskap van Pionius is albei tendens georiënteerde geskrifte en nie betroubare historiese bronne nie. ${ }^{42}$ Daar is 'n sterk moontlikheid dat 'n spesifieke lees van albei gedeeltes in Openbaring die outeurs

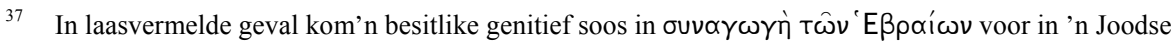
inskripsie van Klein-Asië ("Synagogue of the Hebrews", CIJ 718).

38 CJ Hemer, The Letters to the Seven Churches of Asia in Their Local Setting, Sheffield: JSOT Press, 1986, 7-9 Kyk ook onder andere, DE Aune, Revelation I, Word Biblical Commentary 52A, Dallas, Texas: Word Books, 1997, 162. Kyk A Yarbro Collins, Crisis and Catharsis: the Power of the Apocalypse, Philadelphia: The Westminster Press, 1984, 85.

39 Oor die Jode in Mart. Pol., kyk ook 13.1, 17.2 en 18.2.

40 Hemer, Letters, 8-11.

41 Kyk onder andere LL Thompson, The Book of Revelation. Apocalypse and Empire, New York: Oxford University Press, 1990.

42 E Leigh Gibson argumenteer dat die gedeeltes oor die Joodse deelname aan die vervolging van Christene in die Martelaarskap van Polycarpus beskou kan word as die gevolg van redigerende intervensie wat bedoel is om die 'ver-Joodsing' van Christene te kritiseer, kyk haar "Jewish Antagonism or Christian Polemic: The Case of the Martyrdom of Pionius", Journal of Early Christian Studies 9 (2001), 339-358. 
van die Martelaarskappe geïnspireer het - Polycarp was immers Biskop in Smirna. ${ }^{43}$ Die kernvraag is egter was daar grondige parallelle ter stawing van die aanname dat die term, $\beta \lambda \propto \sigma \phi \eta \mu i ́ \alpha$ 'laster' in Openbaring 2:9 inderdaad dui op die uitlewering van Christene deur Jode aan die Romeinse outoriteite. Tot dusver was dit nog nie vir my moontlik om parallelle in dié verband te vind nie. Die term, duiwel in vers $10 \mathrm{kan}$ moontlik verwys na die Romeinse owerhede, en nie na die Jode nie, aangesien die profeet Johannes die hele wêreld in ag geneem het - afgesien daarvan of hulle Joods of heidens was, of verdorwe deur Satan. ${ }^{44}$ Nóg Openbaring 2:9 nóg Openbaring 3:9 gee 'n duidelike aanduiding dat Jode aktief betrokke was by die vervolging van die navolgers van Jesus Christus. Inteendeel, dit is meer waarskynlik dat die lyding waarna daar in Openbaring 2:9-10 verwys word, deur heidene veroorsaak is, aangesien hulle owerhede elders in dié boek beskuldig van die grusame moorde op die navolgers van Christus (bv. 13:7-10, 15). Afgesien van die negatiewe toon in hierdie frases; sogenaamde Jode en Sinagoge van Satan, is daar niks in Openbaring 2:9 wat dui op'n anti-Judaïsme nie.

Openbaring 3:9, die Filadelfia-verordening, verwys na Jode op soortgelyke wyse as die Smirna-verordening: "Kyk, ek gee jou uit die sinagoge van die Satan, van die wat sê dat hulle Jode is en dit nie is nie, maar lieg - ek sal maak dat hulle kom en voor jou voete neerbuig en erken dat ek jou liefgehad het" (Op. 3:9). ${ }^{45}$ Dié gedeelte verwys na die profesie van die nuwe Jerusalem in Jesaja $60:^{46}$ "en almal wat jou verag het, sal neerbuig by jou voetsole" (Jes. 60:14). ${ }^{47}$ Op. 3:9 kan egter 'n eggo van nog 'n gedeelte uit Jesaja wees: "Hulle sal voor jou neerbuig met die aangesig na die aarde toe en die stof van jou voete lek" (Jes. 49:23). Openbaring se verwysing na Jesaja 60:14 wil moontlik 'n omkering van rolle impliseer. Volgens Jesaja sal die heidene hulleself onderwerp aan Israel. Volgens Openbaring 3:9 sal dié wat sê dat hulle Jode is, die volgelinge van Jesus Christus vereer. Hierdie interpretasie word ondersteun deur 'n verdere verwysing na Jesaja 60:14 verder aan in die verordening aan Filadelfia. Hierdie tweede verwysing bied die voortsetting van 'n gedeelte van Jesaja 60:14, waarna verwys word in Openbaring 3:9 (“...voor jou voete neerbuig"): "Hulle sal jou noem: Stad van die Here, Sion van die heilige van Israel." Die gedeelte word voorveronderstel in die woorde wat gegraveer word op die oorwinnaar, wat soos 'n pilaar van God se tempel sal wees: "En ek sal op hom die naam van my God skrywe en die naam van die stad van my God, van die nuwe Jerusalem wat uit die hemel van my God neerdaal..." Dit wil dus voorkom of dié gedeelte 'n voorspelling is dat 'n gedeelte van die Joodse gemeenskap van Filadelfia ("die wat sê dat hulle Jode is") sal ophou om Jesus te verwerp en eer sal betoon aan die groep volgelinge van Jesus in Filadelfia. Hierdie groep word voorgestel deur die frase, die mense van God in die laaste

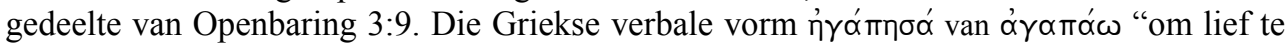
hê" kan die beste geïnterpreteer word as 'n Aoristos wat die ekwivalent van die Hebreeuse Perfektum vorm, "Ek is lief vir", is. ${ }^{48}$ Die frase verwys hier na 'liefhê' met die konnotasie “om gekies te wees," en hou verband met nog 'n verwysing na Jesaja. In Jesaja 43:4 lees

43 DE Aune, Revelation, 1.162, and Marshall, Parables, 183-4, kritiseer die gebruik van Mart. Pol. om Op. 2:9 te verduidelik. Hy kom tot die gevolgtrekking dat die 'Martyrdom' wel beïnvloed kon wees deur die rol van die Jode of Joodse leiers in verband met Jesus se dood, soos voorgestel in die 'Passie-naratief'.

44 RJ Bauckham, The Climax of Prophecy: Studies on the Book of Revelation, Edinburgh: T \& T Clark, 1993, 198.

45 NRSV: “...that I loved you.” Kyk onder.

46 Fekkes, Isaiah, 133-5.

47 Vgl. 1 QM 19:6.

48 With Mussies, Morphology, 338. 
ons: "Ek (God) jou (Israel) liefhet.” In plaas van Israel, verwys die 'jy' in Openbaring 3:9 eerder na Jesus Christus se volgelinge in Filadelfia.

\section{Slot en Epiloog}

Om saam te vat - Openbaring 3:9 herhaal die negatiewe stereotipe van 2:9. By 2:9 voeg dit die voorspelling dat sommige Jode van Filadelfia wel sal aansluit by die binne-groep van Jesus se volgelinge, as die uitverkore mense van God, soos voorgestel in die Filadelfiaverordening. Rituele verdoeming en vervloeking is afwesig in albei Openbaring-gedeeltes en dit wil voorkom of dit in ander gedeeltes van die boek ook afwesig is. Aksies wat voortspruit uit anti-Joodse optrede is ook afwesig. Behoort ons ons bevindinge te beskou as bewyse van anti-Judaïsme? Net soos in die vierde Evangelie, word Jode definitief op 'n negatiewe en stereotipiese wyse in Openbaring beskryf. Daar is egter 'n verskil tussen die Evangelie en Openbaring. In Johannes handel dit oor alle Jode wat nie vir Jesus volg nie; in Openbaring bewys die gedeeltes moontlik na Joodse groepe in 'n plaaslike konteks, wat weier om te glo dat Jesus die Messias is. Albei geskrifte impliseer egter dat daardie Jode wat vir Jesus verwerp, nie deelneem aan die gebeure van die Verlossing nie, dat hulle nie deel van die uitverkore mense is nie, en laastens, dat hulle met Satan geassosieer word. Die naam 'Jode' het as sulks 'n positiewe konnotasie, maar dit wil voorkom of die naam verplaas is na die in-groep van Johannes, die profeet se boodskap. Slegs hierdie siening van Judaïsme is die regte siening, en die keuse om by die groep aan te sluit wat die tipe Judaïsme navolg, word voorgestel as 'n saak van lewe en dood. Die wat sê dat hulle Jode is, word die naam 'Jode' ontsê, en die profesie in die Filadelfia-boodskap voorspel 'n omgekeerde scenario: die wat hulself as Israel beskou, maar vir Jesus ontken, sal in die toekoms verskuif na die Israel volgens Johannes die profeet se perspektief.

Indien die Vierde Evangelie anti-Judaïsme bevat, dan bevat Openbaring ook antiJudaïsme. Die selfbeeld van Joodse gemeentes in Smirna en Filadelfia is geraak deur Johannes se eksklusiewe profesie. Hulle is gekarakteriseer op 'n negatiewe wyse deur die assosiasie met Satan en hulle eie lewenswyse is gediskwalifiseer. Die bevordering van negatiewe stereotipes ten opsigte van Jode, is die eerste stap vir die uitdrukking van antiJudaïsme. Binne sekere historiese omstandighede het dit gelei tot dade van aggressie en selfs pogings om alle Jode dood te maak. Elders het ek geargumenteer dat die voortdurende swartsmeer van Jode in Egipte as Tufoniërs, mense wat geassosieer word met die GriekseEgiptiese anti-God van Chaos en boosheid, Set-Tuphon, kon moontlik 'n uiters belangrike ideologiese faktor vir die regverdiging van die vervolging en uitmoor van Jode in Alexandria en Egipte in 38 en 116 n.C. gewees het. ${ }^{49}$

My Israelse kollega in Amsterdam, Athalya Brenner, sê vir my dat die fenomeen van anti-Judaïsme wat uitgedruk word deur Jode, steeds 'n bewese feit is in die moderne staat van Israel as gevolg van hoogs-konflikterende ideologieë, maar Openbaring het deel geword van die Christelike kanon en Christene behoort hulle tradisie van anti-Judaïsme baie ernstig op te neem. Openbaring 2:9 sowel as 3:9 kon funksioneer, soos ander Nuwe Testamentiese gedeeltes, as 'n regverdiging van Christelike optrede teen Jode. Ek beskou dit as baie belangrik dat dit aangedui word wanneer die werk gebruik word in Christelike diens of ander gemeenskaplike aktiwiteite. Tomson se voorstel om die Nuwe Testament in

49 R Abusch \& JW van Henten, “The Depiction of the Jews as Typhonians and Josephus' Strategy of Refutation in Contra Apionem”, in: LH Feldman \& JR Levison (red.), Josephus' Contra Apionem: Studies in its Character and Context with a Latin Concordance to the Portion Missing in Greek, Leiden: Brill, 1996:271-309. 
dié lig te lees, is baie waardevol. Sy voorstel om te soek vir eenheid binne die diversiteit van Nuwe Testament-gedeeltes wat verband hou met Jode, deur die gedeeltes te lees in kombinasie met gedeeltes uit die Joodse Bybel, en om Rabbiniese metodes van lees te gebruik, is van groot hulp. Hiermee saam dink ek ook dat Christene moet reflekteer oor die hermeneutiese perspektiewe waarin Openbaring gelees kan word - op 'n wyse wat Jode nie seermaak en diskwalifiseer nie. Na my mening noodsaak dit die relativering van Openbaring se aanspraak om die absolute waarheid te wees. Ons behoort te erken dat verskillende godsdienstige groepe, of selfs verskillende godsdienste wel die reg het om aanspraak te maak op die waarheid van hulle eie godsdienstige openbarings. Ons moet aanvaar dat meer as een weg na Verlossing lei. Daar is verskeie oorwegings om uit te brei op 'n relativering van Johannes se eksklusiewe en universele aanspraak op die waarheid. Daar kan essensieel geargumenteer word dat alle godsdienste gelyk is, of dat verskillende godsdienste alternatiewe wêreldsienings tot gevolg kan hê, wat ten minste deur buitestaanders gerespekteer behoort te word. In die verband is daar nog 'n Nuwe Testamentiese geskrif, die brief aan die Efesiërs, wat 'n perspektief op Verlossing kan bied, wat as ' $n$ tweeledige model, ten minste aanvaarbaar vir beide Christene en Jode, kan dien. Christene behoort nie te huiwer om dit aan hulle eie Christelike gemeenskappe uit te wys nie. 